\title{
Effect of Planting Season on Yields of Eight Short-Grain Varieties of Rice Under Irrigation, ${ }^{1,2}$
}

\author{
José Lozano and Fernando Abruña ${ }^{3}$
}

\begin{abstract}
The productivity of eight short grain varieties of rice planted every 3 months over a one-year period was determined under irrigation at Gurabo, at $80 \mathrm{~m}$ of elevation and mean annual temperature of $26.7^{\circ} \mathrm{C}$ and $1,524 \mathrm{~mm}$ of annual rainfall. Caloro and Colusa varieties from California had the lowest average yields for the year and were outyielded by the Spanish varieties Girona, Bahia, and Amposta, which produced $6,160 \mathrm{~kg} / \mathrm{ha}$ of unhulled rice. All varieties had similar yields in September and December plantings. Amposta, Dosel, and Girona were the highest yielders in March plantings, and Amposta, Balilla, Bahía, Girona, and Nano Sollana in June planting. September plantings produced the lowest average yields $(4,581 \mathrm{~kg} / \mathrm{ha})$ of unhulled rice and June planting the highest $(7,045 \mathrm{~kg} / \mathrm{ha})$. Average yield for all varieties and all seasons was $5,678 \mathrm{~kg} / \mathrm{ha}$ of unhulled rice. Time required to produce a crop varied from 81 days for June planting to 117 days for December planting. Results show that three high yielding plantings of these varieties can be grown yearly in similar areas in Puerto Rico when irrigation is available.
\end{abstract}

\section{INTRODUCTION}

Puerto Rico consumes about 180,000 tons of rice yearly valued at $\$ 70$ million, but none is grown locally. About $65 \%$ of the rice consumed in Puerto Rico is of the short grain type imported from California.

Little research has been conducted in Puerto Rico on the productivity of different rice varieties as affected by season of the year and none with short grain types. Abruna and Lozano ${ }^{4}$ studied the effect of season of the year on the productivity of 13 varieties of rice of medium and long grain types over a one-year period at Gurabo, with intermittent flooding. The semidwarf, late maturing, long-grain Sinaloa variety had the highest yields, averaging $5,499 \mathrm{~kg} / \mathrm{ha}(4,910 \mathrm{lb} / \mathrm{acre})$ of unhulled rice per planting. Yields of the 13 varieties tested were not markedly or consistently affected by season of the year. That experiment showed that two plantings with a total yearly production of about $11.2 \mathrm{t} / \mathrm{ha}$ (5 tons/acre) of

'Manuscript submitted to Editorial Board, January 26, 1976.

${ }^{2}$ This paper covers work carried out cooperatively between the Agricultural Research Service, USDA, and the Agricultural Experiment Station, College of Agricultural Sciences, Mayagüez Campus, University of Puerto Rico, Río Piedras, P.R.

${ }^{3}$ Assistant Agronomist, Agricultural Experiment Station, Mayagüez Campus, University of Puerto Rico and Soil Scientist, Agricultural Research Service, USDA, Rio Piedras, P.R., respectively.

4 Abruña, Fernando and Lozano, José, Effects of Season of the Year on Yields of 13 Varieties of Rice Growing in the Humid Region of Puerto Rico, J. Agr. Univ. P.R., 58(1): $11-17,74$ 
unhulled rice can be grown with irrigation in the humid region of Puerto Rico,

This work studied the productivity of eight short-grain varieties of rice planted every 3 months over a one-year period at Gurabo under intensive management and intermittent flooding.

\section{MATERIAL AND METHODS}

The experiments were conducted at the Gurabo Substation, located about $80 \mathrm{~m}$ ( $250 \mathrm{ft}$ ) above sea level with a mean annual temperature of about $26.7^{\circ} \mathrm{C}\left(80^{\circ} \mathrm{F}\right)$. Annual rainfall is about $1,524 \mathrm{~mm}$ (60 in) with a marked dry season generally extending from November through March.

Soil is Toa silty clay, a Mollisol with 3.8\% of organic matter and $\mathrm{pH}$ of 5.8. Total exchange capacity is $29 \mathrm{meq} / 100 \mathrm{~g}$ of soil with $18 \mathrm{meq}$ of exchangeable bases.

Eight short grain varieties were tested: Amposta, Bahía, Balilla, Dosel, Girona, Nano Sollana, Caloro, and Colusa. Caloro, Colusa, Balilla, and Amposta are of the pearl type. Caloro and Colusa were developed in California and the others in Spain. Plantings were in September, December, March, and June 1974-75 in a randomized block design with $4 \times 4 \mathrm{~m}$ plots and were replicated five times.

Seeds were planted in rows $20 \mathrm{~cm}$ ( 8 in) apart at the rate of $112 \mathrm{~kg} / \mathrm{ha}$ (100 lb/acre) and irrigated by intermittent flooding. One hundred and twelve $\mathrm{kg} / \mathrm{ha}$ (100 lb/acre) each of $\mathrm{N}, \mathrm{P}_{2} \mathrm{O}_{5}$ and $\mathrm{K}_{2} \mathrm{O}$ were applied to all plots, half at planting time and the remainder 30 days later.

Plots were sprayed twice with Diazinon ${ }^{5}$ to control insects and protected from birds by plastic netting installed after the rice headed. Rats were controlled by using poison baits. Propanil at the rate of $16.8 \mathrm{l} / \mathrm{ha}$ (11/2 gal/acre) diluted in 200 l (50 gal) of water was applied to control weeds when they developed their second pair of leaves.

When grain reached about $20 \%$ moisture content it was harvested, threshed, and dried to $12 \%$ moisture before weighing.

\section{RESULTS AND DISCUSSION}

Table 1 shows no significant difference in the average productivity for the year among the six Spanish varieties, although highest yields, averaging $6,160 \mathrm{~kg} / \mathrm{ha}$ of unhulled rice $(5,500 \mathrm{lb} / \mathrm{acre})$ per planting were produced by Amposta, Bahía, and Girona. Caloro and Colusa had the lowest average yields, being significantly outyielded by Girona, Bahía, and Amposta.

5 Trade names are used in this publication solely for the purpose of providing specific information. Mention of a trade name does not constitute a guarantee or warranty of equipment or materials by the Agricultural Experiment Station of the University of Puerto Rico or an endorsement over other equipment or materials not mentioned. 
There was no significant difference in yields between varieties in September and December plantings. Amposta, Dosel, Colusa, and Girona had the highest yields in the March planting. Amposta, Balilla, Bahía, Girona, and Nano Sollana were highest in the June planting.

December and March plantings had similar yields, averaging 5,533 $\mathrm{kg} / \mathrm{ha}(4,940 \mathrm{lb} /$ acre $)$ of unhulled rice. September planting, 4,581 kg/ha (4,090 1b/acre), averaged the lowest of unhulled rice. June planting,

TABLE 1. - Effect of season on yield of eight short-grain rice varieties at Gurabo

\begin{tabular}{|c|c|c|c|c|c|c|c|c|c|c|}
\hline \multirow{3}{*}{ Variety } & \multicolumn{10}{|c|}{ Yields of unhulied rice produced when rice was planted during month indicated- } \\
\hline & \multicolumn{2}{|c|}{ September } & \multicolumn{2}{|c|}{ December } & \multicolumn{2}{|l|}{ March } & \multicolumn{2}{|l|}{ June } & \multicolumn{2}{|c|}{ Average } \\
\hline & $\begin{array}{c}\mathrm{Kgl} \\
\mathrm{ha}\end{array}$ & $\begin{array}{c}\mathrm{Lb} / \\
\text { acre }\end{array}$ & $\begin{array}{c}\mathrm{Kgl} \\
h a\end{array}$ & $\begin{array}{l}\text { Lb/ } \\
\text { acre }\end{array}$ & $\begin{array}{l}\mathrm{Kgl} \\
\mathrm{ha}\end{array}$ & \begin{tabular}{|l|}
$L b /$ \\
acre
\end{tabular} & $\begin{array}{l}\mathrm{Kgl} \\
\mathrm{ha}\end{array}$ & \begin{tabular}{|l|} 
Lbl \\
acre
\end{tabular} & $\begin{array}{l}K g / \\
h a\end{array}$ & \begin{tabular}{|l}
$L b /$ \\
acre
\end{tabular} \\
\hline Amposta ${ }^{1}$ & 5,320 & 4,750 & 5,902 & 5,270 & $5,790 \mathrm{ab}^{3}$ & 5,170 & $7,874 \mathrm{a}$ & 7,030 & 6,227 a & 5,560 \\
\hline Bahia & 4,816 & 4,300 & 6,339 & 5,660 & 5,622 bede & 5,020 & $7,739 \mathrm{ab}$ & 6,910 & $6,126 \mathrm{ab}$ & 5,470 \\
\hline Balilla ${ }^{2}$ & 4,704 & 4,200 & 4,816 & 4,300 & 4,995 bcdef & 4,460 & 7,392 abcd & 6,600 & $5,477 \mathrm{abc}$ & 4,890 \\
\hline Dosel $^{2}$ & 4,491 & 4,010 & 5,768 & 5,150 & 5,690 abcd & 5,080 & $6,294 \mathrm{~d}$ & 5,620 & $5,555 a b c$ & 4,960 \\
\hline Girona $^{2}$ & 5,208 & 4,650 & 5,264 & 4,700 & $6,474 \mathrm{a}$ & 5,780 & $7,582 \mathrm{abc}$ & 6,770 & $6,137 \mathrm{ab}$ & 5,480 \\
\hline $\begin{array}{l}\text { Nano- } \\
\text { Sollana }\end{array}$ & 4,749 & 4,240 & 5,499 & 4,910 & 4,872 def & 4,350 & 6,854 abcd & 6,120 & $5,499 a b c$ & 4,910 \\
\hline Caloro & 3,517 & 3,140 & 5,848 & 5,221 & $4,570 \mathrm{f}$ & 4,080 & $6,350 \mathrm{~cd}$ & 5,670 & $5,074 \mathrm{c}$ & 4,530 \\
\hline Colusa $^{1}$ & 3,819 & 3,410 & 5,399 & 4,820 & $5,734 a b c$ & 5,120 & $6,294 \mathrm{~d}$ & 5,620 & $5,309 \mathrm{c}$ & 4,740 \\
\hline Average & 4,581 & 4,090 & 5,600 & 5,000 & 5,466 & 4,880 & 7,045 & 6,290 & 5,678 & 5,070 \\
\hline $\begin{array}{l}\text { Average nur } \\
\text { of days fro } \\
\text { planting t } \\
\text { harvest }\end{array}$ & & 95 & & 117 & & 99 & & 81 & & 98 \\
\hline
\end{tabular}

"Varieties producing a "Pearl" type grain.

2 Varieties producing transluscent type grain.

${ }^{3}$ Values with one or more letters in common do not differ statistically $(\mathrm{P}=.05$ )

with $7,045 \mathrm{~kg} / \mathrm{ha}(6,290 \mathrm{lb} / \mathrm{acre})$ of unhulled rice, averaged the highest yields. Average yields for all varieties and seasons was $5,678 \mathrm{~kg} / \mathrm{ha}$ (5,070 lb/acre) of unhulled rice per planting.

Time required to produce a crop varied from 81 days for the June planting, which had highest yields, to 117 days for December planting. Average for all seasons and varieties was 98 days. The Spanish varieties require about 170 days to mature in Spain.

A 26 ha (65 acre) commercial planting of Girona at Vega Baja produced an average of $5,712 \mathrm{~kg} / \mathrm{ha}(5,100 \mathrm{lb} / \mathrm{acre})$ of unhulled rice. The rice was milled, polished, and sold in Puerto Rico. Milling qualities were good, with yields of about $60 \%$ of whole grain of very good appearance and little chalkiness. This variety is resistant to lodging because in Puerto Rico it grows only to a height of about $1 \mathrm{~m}$. 
Table 2 shows the yields at different seasons of the ratoon ${ }^{6}$ crop of varieties studied. Fair yields, averaging $2,542 \mathrm{~kg} / \mathrm{ha}(2,270 \mathrm{lb} / \mathrm{acre})$ of unhulled rice were obtained from the ratoon of seed crops harvested in April and August, but low yields were obtained from the ratoon crops harvested in September and January. Ratoons produced a crop in an average of only 58 days.

TABLE 2. - Effect of season on rutoon crop of eight short-grain rice varieties at Gurabo

\begin{tabular}{|c|c|c|c|c|c|c|c|c|c|c|}
\hline \multirow{3}{*}{ Variety } & \multicolumn{10}{|c|}{$\begin{array}{l}\text { Yields of unhulled rice from ratoon crop following } \\
\text { seed crop harvested on date indicated - }\end{array}$} \\
\hline & \multicolumn{2}{|l|}{ April 3} & \multicolumn{2}{|c|}{ August 25} & \multicolumn{2}{|c|}{ Sept. 16} & \multicolumn{2}{|c|}{ January 20} & \multicolumn{2}{|c|}{ Average } \\
\hline & $\underset{\mathrm{Kgl}}{\mathrm{Kg}}$ & $\begin{array}{l}\text { Lbl } \\
\text { acre }\end{array}$ & $\begin{array}{c}K g / \\
h a\end{array}$ & $\begin{array}{l}\text { Lbl } \\
\text { acre }\end{array}$ & $\begin{array}{l}\mathrm{Kg} / \\
\mathrm{ha}\end{array}$ & $\begin{array}{l}\text { Lb/ } \\
\text { acre }\end{array}$ & $\begin{array}{c}K g l \\
h a\end{array}$ & $\begin{array}{l}\text { Lbl } \\
\text { acre }\end{array}$ & Kgl & $\begin{array}{l}\text { Lb/ } \\
\text { acre }\end{array}$ \\
\hline Amposta & $616 d^{1}$ & 550 & $1,602 \mathrm{e}$ & 1,430 & 1,053 & 940 & $963 \mathrm{e}$ & 860 & $1,064 \mathrm{f}$ & 950 \\
\hline Bahía & 2,621 abcd & 2,340 & $2,397 \mathrm{bcd}$ & 2,140 & 986 & 880 & $1,658 \mathrm{abc}$ & 1,480 & 1,915 bcdef & 1,710 \\
\hline Balilla & $2,610 \mathrm{abcd}$ & 2,330 & $1,826 \mathrm{de}$ & 1,630 & 806 & 720 & $1,792 \mathrm{ab}$ & 1,600 & 1,758 bcdef & 1,570 \\
\hline Dosel & $4,234 \mathrm{a}$ & 3,780 & $3,405 \mathrm{a}$ & 3,040 & 1,702 & 1,520 & $1,557 \mathrm{abcd}$ & 1,390 & $2,733 a$ & 2,440 \\
\hline Girona & $1,366 \mathrm{bc}$ & 1,220 & $1,389 \mathrm{e}$ & 1,240 & 907 & 810 & 1,378 bcde & 1,230 & 1,266 ef & 1,130 \\
\hline $\begin{array}{l}\text { Nano- } \\
\text { Sollana }\end{array}$ & $3,035 \mathrm{abc}$ & 2,710 & $2,811 \mathrm{ab}$ & 2,510 & 1,198 & 1,070 & 1,355 bcde & 1,210 & 2,106 abcd & 1,880 \\
\hline Caloro & $2,565 \mathrm{abcd}$ & 2,290 & $2,733 a b c$ & 2,440 & 1,456 & 1,300 & $1,344 \mathrm{a}$ & 1,200 & $2,162 \mathrm{abc}$ & 1,930 \\
\hline Colusa & $3,326 \mathrm{ab}$ & 2,970 & $2,722 \mathrm{abc}$ & 2,430 & 1,523 & 1,360 & 1,926 a & 1,720 & $2,374 a b$ & 2,120 \\
\hline Average & 2,542 & 2,270 & 2,362 & 2,110 & 1,210 & 1,080 & 1,568 & 1,400 & 1,994 & 1,780 \\
\hline $\begin{array}{l}\text { Average } n \\
\text { days be } \\
\text { vest of } \\
\text { and rat }\end{array}$ & $\begin{array}{l}\text { number of } \\
\text { etween har- } \\
\text { seed crop } \\
\text { toon crop }\end{array}$ & 52 & & 54 & & 54 & & 74 & & \\
\hline
\end{tabular}

${ }^{1}$ Values with one or more letters in common do not differ statistically $(P=.05)$

Dosel had the highest average production and the most consistently high ratoon yields, with highest average yields in April, August, and September crops.

Results show that, in spite of a seasonal effect, short-grain rice varieties, as well as long- and medium-grain ones, can produce three high yielding crops per year. In commercial plantings at Vega Baja three good crops of Girona variety were harvested successfully on the same land in less than 12 months.

\section{RESUMEN}

Se investigó el efecto de la época de siembra sobre el rendimiento de ocho variedades de arroz de grano corto sembradas en regadío cada 3 meses. El estudio, realizado en Gurabo, se prolongó por un año. Las seis variedades españolas arrojaron rendimientos medios similares durante el año. Las variedades Girona, Bahía y Amposta superaron en rendimiento a Caloro y Colusa, ambas de California.

"Crop produced by new shoots that sprout after harvesting. 
En las siembras de septiembre y diciembre no hubo diferencia significativa en rendimiento de las distintas variedades. En las siembras de marzo, las variedades Amposta, Dosel y Girona fueron las que produjeron más. En las de junio, Amposta, Balilla, Bahía, Girona y Nano Sollana fueron las que más produjeron.

Las siembras de diciembre y marzo produjeron casi igual: $5,533 \mathrm{~kg}$./ha. (4,940 libras por cuerda) de arroz en cáscara, en promedio. Los rendimientos más bajos se obtuvieron en la siembra de septiembre con un promedio de 4,581 kg./ha. (4,090 libras por cuerda) de arroz en cáscara y los más altos en la siembra de junio con un promedio de 7,045 kg./ha. $(6,290$ libras por cuerda). El rendimiento medio por cosecha para todas las variedades y épocas del año fue de $5,678 \mathrm{~kg}$./ha. (5,070 libras por cuerda).

Una siembra comercial de 26 ha. (65 cuerdas) de la variedad Girona en Vega Baja produjo $5,712 \mathrm{~kg}$./ha. (5,100 libras por cuerda) de arroz en cáscara. Este demostró tener muy buenas propiedades molineras y apariencia atractiva.

La siembra de junio produjo una cosecha sólo 81 días después de sembrada, mientras que la de diciembre tardó 117 días. El promedio para todas las variedades y épocas del año fue 98 días. Las variedades espan̂olas tardan entre 5 y 6 meses en producir una cosecha en España.

Estos datos señalan que es factible lograr tres cosechas de arroz al año en Puerto Rico donde haya riego disponible. En siembras comerciales en Vega Baja se cosecharon tres siembras de la variedad Girona en menos de 12 meses. 